\title{
SUlFENTRAZONE EFFICIENCY ON Ipomoea hederifolia AND Ipomoea quamoclit as INFLUENCED By RAIN ANd SUgaRCANE STRAW ${ }^{1}$
}

\author{
Eficácia de Sulfentrazone em Ipomoea hederifolia e Ipomoea quamoclit Influenciada pela \\ Ocorrência de Chuva e Palha de Cana
}

CORREIA, N.M. ${ }^{2}$, CAMILO, E.H. ${ }^{3}$, and SANTOS, E.A. ${ }^{4}$

\begin{abstract}
The aim of this study was to assess the capacity of sulfentrazone applied in preemergence in controlling Ipomoea hederifolia and Ipomoea quamoclit as a function of the time interval between herbicide application and the occurrence of rain, and the presence of sugarcane straw on the soil surface. Two greenhouse experiments and one field experiment were conducted. For the greenhouse experiments, the study included three doses of sulfentrazone applied by spraying $0,0.6$, and $0.9 \mathrm{~kg} \mathrm{ha}^{-1}$, two amounts of straw on the soil (0 and $10 \mathrm{t} \mathrm{ha}^{-1}$ ), and five time intervals between the application of herbicide and rain simulation $(0,20,40,60$, and 90 days). In the field experiment, five herbicide treatments (sulfentrazone at 0.6 and $0.9 \mathrm{~kg} \mathrm{ha}^{-1}$, sulfentrazone + hexazinone at $0.6+0.25 \mathrm{~kg} \mathrm{ha}^{-1}$, amicarbazone at $1.4 \mathrm{~kg} \mathrm{ha} \mathrm{k}^{-1}$, and imazapic at $0.147 \mathrm{~kg} \mathrm{ha}^{-1}$ ) and two controls with no herbicide were studied. Management conditions with or without sugarcane straw on the soil were also assessed. From the greenhouse experiments, sulfentrazone application at $0.6 \mathrm{~kg} \mathrm{ha}^{-1}$ was found to provide for the efficient control of I. hederifolia and I. quamoclit in a dry environment, with up to 90 days between herbicide application and rain simulation. After herbicide application, $20 \mathrm{~mm}$ of simulated rain was enough to leach sulfentrazone from the straw to the soil, as the biological effects observed in I. hederifolia and I. quamoclit remained unaffected. Under field conditions, either with or without sugarcane straw left on the soil, sulfentrazone alone (0.6 or $\left.0.9 \mathrm{~kg} \mathrm{ha}^{-1}\right)$ or sulfentrazone combined with hexazinone $\left(0.6+0.25 \mathrm{~kg} \mathrm{ha}^{-1}\right)$ was effective in the control of $I$. hederifolia and I. quamoclit, exhibiting similar or better control than amicarbazone $\left(1.4 \mathrm{~kg} \mathrm{ha}^{-1}\right)$ and imazapic $\left(0.147 \mathrm{~kg} \mathrm{ha}^{-1}\right)$.
\end{abstract}

Keywords: Boral ${ }^{\circledR}$, raw sugarcane, morning glory, herbicide retention, Saccharum officinarum.

\begin{abstract}
RESUMO-Objetivou-se neste trabalho avaliar o controle em pré-emergência de Ipomoea hederifolia e Ipomoea quamoclit pelo herbicida sulfentrazone em função do intervalo de tempo entre a aplicação e a ocorrência de chuva e da manutenção ou não de palha de cana-de-açúcar na superficie do solo. Três experimentos foram desenvolvidos: dois em casa de vegetação e um em campo. Nos experimentos em casa de vegetação, foram estudadas três doses de sulfentrazone $(0,0,6$ e $0,9 \mathrm{~kg}$ ha-1) pulverizado

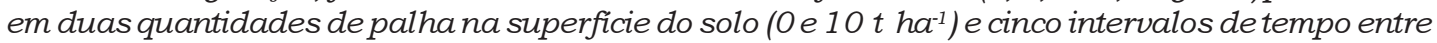
a sua aplicação e a simulação de chuva (0,20, 40, 60 e 90 dias). No experimento em campo, foram avaliados cinco tratamentos de herbicida (sulfentrazone a 0,6 e $0,9 \mathrm{~kg} \mathrm{ha-1}$; sulfentrazone + hexazinone a 0,6 + 0,25 kg ha-1; amicarbazone a 1,4 kg ha-1; e imazapic a 0,147 kg ha $\mathrm{kg}^{-1}$ ) e duas testemunhas sem aplicação. A manutenção ou não da palha de cana sobre o solo também foi estudada. Em casa de vegetação, a aplicação de $0,6 \mathrm{~kg} \mathrm{ha^{-1 }}$ de sulfentrazone foi suficiente para o controle adequado de I. hederifolia e I. quamoclit num ambiente seco com até 90 dias sem chuva após a aplicação. Os $20 \mathrm{~mm}$ de chuva simulados após a aplicação do herbicida foram su ficientes para removero sulfentrazone da palha para o solo, pois o efeito biológico de controle de I. hederifolia e I. quamoclit não foi alterado. Em campo, sem ou com a permanência de palha de cana sobre o solo, o sulfentrazone
\end{abstract}

Recebido para publicação em 15.2.2012 e aprovado em 20.8.2012.

2 Professor, Dr., Dep. de Fitossanidade, Universidade Estadual Paulista - UNESP, Campus de Jaboticabal-SP, Via de Acesso Prof. Paulo Donato Castellane, s/n 14.884-900 Jaboticabal-SP, <correianm@fcav.unesp.br>; ${ }^{3}$ Eng $^{0}$-Agr ${ }^{\circ}$., formado pela UNESP, Campus de Jaboticabal-SP, ${ }^{4}$ Doutorando do Programa de Pós-Graduação em Agronomia - Produção Vegetal, UNESP, Campus de Jaboticabal-SP.

Planta Daninha, Viçosa-MG, v. 31, n. 1, p. 165-174, 2013 
isolado $\left(0,6\right.$ e $\left.0,9 \mathrm{~kg} \mathrm{ha}^{-1}\right)$ ou em mistura com hexazinone $\left(0,6+0,25 \mathrm{~kg} \mathrm{ha}^{-1}\right)$ foi eficaz para

I. hederifolia e I. quamoclit, com resposta similar ou melhor que a do amicarbazone $\left(1,4 \mathrm{~kg} \mathrm{ha}^{-1}\right)$ eimazapic $\left(0,147 \mathrm{~kg} \mathrm{ha}^{-1}\right)$.

Palavras-chave: Boral $^{\circledR}$, cana crua, corda-de-viola, retenção de herbicidas, Saccharum officinarum.

\section{INTRODUCTION}

In the southeast and midwest regions of Brazil, sugarcane harvest begins in April or May, extending to November or December of the same year. After cutting, crop treatments such as weed management are necessary to ensure new sprouting and plant growth. During the drier periods of the year (June, July, and August), herbicide application can be conducted during the pre-emergence, post-harvest, or post-emergence stages of the crop, when the soil moisture has been restored. However, herbicides used during the dry season should be highly water-soluble and have low or moderate soil adsorption to ensure that, even under low moisture conditions, part of the product is desorbed to the soil solution and will be available for absorption by the seedling radicle and/or hypocotyl.

Sulfentrazone is listed as an herbicide for use in sugarcane production during the dry season and is specifically recommended for the pre-emergence control of dicotyledonous and monocotyledonous species in agricultural areas used for sugarcane, coffee, citrus, eucalyptus, and soy crops as well as nonagricultural areas in Brazil. Sulfentrazone is highly water-soluble (solubility $=490 \mathrm{mg} \mathrm{L}^{-1}$ ), nonvolatile (vapor pressure $=1.0 \times 10^{-9} \mathrm{mmHg}$ at $\left.25{ }^{\circ} \mathrm{C}\right)$, anionic $(\mathrm{pK}=6.56)$, and hydrophilic $\left(\mathrm{K}_{\mathrm{ow}}=1.48\right)$ (Senseman, 2007; Rodrigues and Almeida, 2011). These parameters convey the stability of the molecule and its affinity for water, which underlie the potential losses of the herbicide to the environment.

Sugarcane mill factories and their suppliers have adapted to the application of herbicides during the dry season, but both have experienced difficulty with weed control in recent years. Leftover and unburned straw from sugarcane cutting may compromise the ability of residual herbicide to reach the soil. The effect of straw on herbicide efficacy depends on the physical and chemical attributes of the herbicides, such as solubility, vapor pressure, and polarity (Rodrigues, 1993). Rain or irrigation, time following the application of herbicide, and changes in the chemical constitution of the decomposing plant material may also strongly influence herbicide retention by straw (Correia et al., 2007). When straw remains on the soil, herbicides are potentially lost by photodegradation, volatilization, and even adsorption to plant residues. The degree of decomposition or plant residue age may affect its ability to adsorb the herbicide (Mersie, 2006).

On the experimental site of the present study, there was increased infestation by vine species, including Ipomoea and Merremia species, later in the growing season. It is possible that sugarcane straw remaining on the soil surface may create a favorable environment for the seed germination and the development of these weeds due to a reduced daily temperature range, increased soil moisture retention, and improved physical and chemical soil attributes. Correia and Durigan (2004) reported that the emergence of Ipomoea grandifolia, I. hederifolia, and I. quamoclit was not influenced by straw at the levels included in their study $\left(5,10\right.$, and $\left.15 \mathrm{t} \mathrm{ha}^{-1}\right)$. Contrary to this finding, however, an increased number of I. quamoclit seedlings emerged, and a greater biomass accumulation was observed, in the presence of mulch compared to treatment without straw.

Approximately $74 \%$ of the Ipomoea and Merremia species found in southeastern Brazil are vine plants with versatile stems and branches that intertwine with neighboring plants and grow over obstacles (Kissmann and Groth, 1999). In addition to the damage they cause by competing for water, light, nutrients, and space, these species cause serious damage to sugarcane at harvest time because they compromise the performance of machines used for harvesting along with the quality of the harvested product. 
The present study was conducted to test the hypothesis that sugarcane straw on the soil surface does not affect the herbicidal efficacy of sulfentrazone, whose weed control potential remains uncompromised for an extended period between the application and the first occurrence of rain. The aim of this study was to assess the efficacy of sulfentrazone, applied during the preemergence period, for the control of I. hederifolia and I. quamoclit, with different time intervals between herbicide application and the occurrence of rain, with or without sugarcane straw on the soil surface.

\section{MATERIALS AND METHODS}

The study included three experiments; two were conducted in a greenhouse and one was conducted in the field.

Two separate greenhouse experiments were conducted for I. hederifolia and I. quamoclit in pots, from July 6 to November 2, 2010 at the Department of Phytosanitary Sciences (Departmento de Fitossanidade) at UNESP, Jaboticabal Campus, São Paulo State, Brazil.

A completely randomized distribution was used for the greenhouse experiments, with four replicates in a $3 \times 5 \times 2$ factorial design. The study included three concentrations of sulfentrazone applied by spraying $0,0.6$, and $0.9 \mathrm{~kg} \mathrm{ha}^{-1}$, two different amounts of straw on the soil ( 0 and $\left.10 \mathrm{tha}^{-1}\right)$, and five time intervals between the application of herbicide and rain simulation $(0,20,40,60$, and 90 days).

Each experimental unit consisted of one 8-L plastic pot of soil. The substrate used was a 3:1:1 mixture of soil, sand, and organic compost.

After mechanical harvesting of the sugarcane plants (variety RB 867515), straw remaining on the soil was collected and taken to the greenhouse and allowed to dry completely.

Seeds of $I$. hederifolia (1.96 $\left.\mathrm{g} \mathrm{pot}^{-1}\right)$ and I. quamoclit ( $\left.1.57 \mathrm{~g} \mathrm{pot}^{-1}\right)$ were homogeneously distributed in each pot and sown approximately $1 \mathrm{~cm}$ below the soil surface. For treatments with straw, a uniform layer of sugarcane straw was placed on each pot after sowing, in quantities corresponding to the two treatment levels. The straw was cut into small fragments less than or equal to the diameter of the pots.

The bottoms of the pots were covered with a sheet of newspaper to prevent soil loss. Each pot was placed on a plastic container with a diameter larger than that of the pot and without holes to ensure a consistent watering regime. The soil moisture was monitored on a daily basis. Water was added to the containers as needed and was distributed through the soil by capillary action.

Sulfentrazone was sprayed on the weeds at the indicated doses during pre-emergence on July 7, 2010, between 9:35 and 9:45 a.m. A backpack sprayer equipped with two flatfan nozzles (XR 11002) spaced $0.5 \mathrm{~m}$ apart and calibrated to deliver an equivalent of $200 \mathrm{~L} \mathrm{ha}^{-1}$ was used at a constant pressure of $1.7 \mathrm{kgf} \mathrm{cm}^{-2}$. At the time of application, the soil was dry, and the following conditions were recorded: $60 \%$ relative humidity, $21.2{ }^{\circ} \mathrm{C}$ air temperature, $25.7^{\circ} \mathrm{C}$ soil temperature (at a depth of $5 \mathrm{~cm}$ ), $1.0 \mathrm{~km} \mathrm{~h}^{-1}$ wind speed, and approximately $5 \%$ cloud coverage.

Rain simulation, equivalent to $20 \mathrm{~mm}$ of water, was conducted immediately after sulfentrazone application (day 0) or 20, 40, 60, or 90 days after.

Fourteen and 28 days after rain simulation (DARS), the total emerged plants were counted. At 28 DARS, plants were cut close to the soil surface, placed inside paper bags, and dried in a forced air circulation oven at $50{ }^{\circ} \mathrm{C}$ until constant weight, when the shoot biomass was then quantified.

The data were subjected to the analysis of variance by the F-test. The significance of the effects of each treatment or the interactions between them was determined using Tukey's test (for herbicide and straw) at 5\% probability or by polynomial fitting of the data (for the rain interval).

The field experiment was conducted from July 2010 to January 2011 at a commercial sugarcane production site (Morumbi farm) in the municipality of Guariba, São Paulo. The SP 91-1049 sugarcane variety, at its fifth cutting, was mechanically harvested on July 11,2010 , with $14 \mathrm{t} \mathrm{ha}^{-1}$ straw left on the soil. 
A randomized block design was used for the field experiment, with four replicates in a $7 \times 2$ split-plot design. The field study included five herbicide treatments (sulfentrazone at 0.6 and $0.9 \mathrm{~kg} \mathrm{ha}^{-1}$, sulfentrazone + hexazinone at $0.6+0.25 \mathrm{~kg} \mathrm{ha}^{-1}$, amicarbazone at $1.4 \mathrm{~kg} \mathrm{ha}^{-1}$, and imazapic at $0.147 \mathrm{~kg} \mathrm{ha}^{-1}$ ) and two controls without herbicide application. Weed infestation was permitted in the first control, and weeds were manually removed in the second control. In each subplot, management with or without sugarcane straw was assessed.

Plots (for the herbicide and control treatments) were $6.0 \mathrm{~m}$ wide and $12.0 \mathrm{~m}$ long, totaling $72.0 \mathrm{~m}^{2}$, and each plot contained four sugarcane rows running the length of the plot. Within each plot, the subplots were demarcated (for management with or without straw) and were $6.0 \mathrm{~m}$ wide and $6.0 \mathrm{~m}$ in length, with an area of $18.0 \mathrm{~m}^{2}(4.5 \mathrm{~m} \mathrm{x} 4.0 \mathrm{~m})$ where the assessments were conducted.

After cane cutting and before herbicide application, the experimental site was artificially infested by sowing $I$. hederifolia $\left(0.98 \mathrm{~g} \mathrm{~m}^{-2}\right)$ and I. quamoclit $\left(0.79 \mathrm{~g} \mathrm{~m}^{-2}\right)$ seeds. Before sowing, straw covering the sugarcane rows was removed, and a rake was used to form inter-rows. A garden hoe was used to make a shallow furrow (up to $3 \mathrm{~cm}$ in depth) at the interrows, into which the seeds were deposited. Straw was uniformly deposited over the interrows for the treatments with straw. For the treatments without straw, all the straw was removed from the sugarcane rows and interrows before planting.

Herbicides were applied during the preemergence of weeds and cultivated plants on July 17, 2010, between 10:15 and 11:35 a.m. A manual backpack sprayer equipped with six flat-fan nozzles (TTI 11002) and calibrated to deliver an equivalent of $200 \mathrm{~L} \mathrm{ha}^{-1}$ was used with a constant pressure of $2.0 \mathrm{kgf} \mathrm{cm}^{-2}$. At the time of herbicide application, the soil was dry, and the edaphoclimatic conditions were as follows: 54 to $62 \%$ relative humidity, 22.6 to $25.3^{\circ} \mathrm{C}$ air temperature, 18.7 to $19.8^{\circ} \mathrm{C}$ soil temperature, 13 to $15 \mathrm{~km} \mathrm{~h}^{-1}$ wind speed, and approximately $5 \%$ cloud coverage.

Visible damage to the sugarcane plants was assessed 16, 34, and 56 days after application
(DAA) of herbicide on a scale of 0 to $100 \%$, where $0 \%$ indicates no visible damage and $100 \%$ indicates plant death.

At 34, 56, 92, and 184 DAA, visual assessments for weed control were conducted, and scores were assigned from 0 to $100 \%$, where $0 \%$ indicates no visible sign of control and $100 \%$ indicates weed death.

Weed density was assessed at 92 DAA by counting the total number of plants for each species in six $0.225-\mathrm{m}^{2}$ sections that were randomly selected within the subplots.

The results were subjected to the analysis of variance by the F-test. The significance of the effects of each treatment and the interactions between them was determined using Tukey's test at 5\% probability. Plant density data were not analyzed statistically.

\section{RESULTS AND DISCUSSION}

For the greenhouse experiments, each factor and the interactions between them were significant for weed density and biomass, with the exception of the straw $\mathrm{x}$ rain $\mathrm{x}$ herbicide interaction, which was not significant for any of the attributes assessed. Given the proposed aim, we chose to split the interactions into rain $\mathrm{x}$ herbicide and straw $\mathrm{x}$ herbicide.

For the rain $\mathrm{x}$ herbicide interaction (Tables 1 and 2), we observed that for all rain intervals and at sulfentrazone doses of 0.6 and $0.9 \mathrm{~kg} \mathrm{ha}^{-1}$, the density and biomass did not vary for the two species assessed, except for I. hederifolia 14 DARS. In this case, the rain simulation soon after the herbicide application at the highest sulfentrazone dose resulted in a lower plant density, which differed from the results obtained with $0.6 \mathrm{~kg} \mathrm{ha}^{-1}$ sulfentrazone.

For both sulfentrazone doses of 0.6 and $0.9 \mathrm{~kg} \mathrm{ha} \mathrm{h}^{-1}$, no differences were observed among the different rain treatments for any of the factors assessed (Figures 1 and 2). Thus, the control of I. hederifolia and I. quamoclit by the herbicide did not depend on the amount of time between the herbicide application and first rain (within 90 days). Without herbicide application, however, the plant density and biomass depended on the rain interval; a polynomial fit of the data was obtained in all of these cases, except for the biomass of 
Table 1 - Plant density of Ipomoea hederifolia at 14 and 28 days after rain simulation (DARS) and shoot biomass at 28 DARS, for different periods of rain simulation and sulfentrazone doses

\begin{tabular}{|c|c|c|c|c|c|c|c|c|c|}
\hline \multirow{4}{*}{$\begin{array}{l}\text { Rain simulation - } \\
\text { Days of herbicide } \\
\text { application }\end{array}$} & \multicolumn{9}{|c|}{ Sulfentrazone doses $\left(\mathrm{kg} \mathrm{ha}^{-1}\right)$} \\
\hline & 0 & 0.6 & 0.9 & 0 & 0.6 & 0.9 & 0 & 0.6 & 0.9 \\
\hline & \multicolumn{6}{|c|}{ Plant density (unit pot $^{-1}$ ) } & \multicolumn{3}{|c|}{ Biomass $\left(\mathrm{g} \mathrm{pot}^{-1}\right)$} \\
\hline & \multicolumn{3}{|c|}{14 DARS } & \multicolumn{3}{|c|}{28 DARS } & \multicolumn{3}{|c|}{28 DARS } \\
\hline 0 & $47.88 \mathrm{C}^{1 / 1}$ & $17.88 \mathrm{~B}$ & $6.50 \mathrm{~A}$ & $52.75 \mathrm{~B}$ & $4.25 \mathrm{~A}$ & $0.00 \mathrm{~A}$ & $2.99 \mathrm{~B}$ & $0.42 \mathrm{~A}$ & $0.00 \mathrm{~A}$ \\
\hline 20 & $40.00 \mathrm{~B}$ & $13.62 \mathrm{~A}$ & $11.75 \mathrm{~A}$ & $45.50 \mathrm{~B}$ & $2.50 \mathrm{~A}$ & $0.62 \mathrm{~A}$ & $2.33 \mathrm{~B}$ & $0.01 \mathrm{~A}$ & $0.07 \mathrm{~A}$ \\
\hline 40 & $27.62 \mathrm{~B}$ & $16.38 \mathrm{~A}$ & $9.00 \mathrm{~A}$ & $43.38 \mathrm{~B}$ & $6.25 \mathrm{~A}$ & $3.50 \mathrm{~A}$ & $2.54 \mathrm{~B}$ & $0.04 \mathrm{~A}$ & $0.07 \mathrm{~A}$ \\
\hline 60 & $37.12 \mathrm{~B}$ & $12.25 \mathrm{~A}$ & $6.00 \mathrm{~A}$ & $48.25 \mathrm{~B}$ & $1.50 \mathrm{~A}$ & $2.00 \mathrm{~A}$ & $2.79 \mathrm{~B}$ & $0.03 \mathrm{~A}$ & $0.02 \mathrm{~A}$ \\
\hline 90 & $51.50 \mathrm{~B}$ & $8.38 \mathrm{~A}$ & $7.38 \mathrm{~A}$ & $59.25 \mathrm{~B}$ & $2.62 \mathrm{~A}$ & $0.50 \mathrm{~A}$ & $3.14 \mathrm{~B}$ & $0.03 \mathrm{~A}$ & $0.01 \mathrm{~A}$ \\
\hline LSD & \multicolumn{3}{|c|}{8.38} & \multicolumn{3}{|c|}{8.69} & \multicolumn{3}{|c|}{0.50} \\
\hline
\end{tabular}

1/ Based on Tukey's test at $5 \%$ probability; averages are followed by capital letters, and different letters within each row (for the same DARS) indicate the differences among the three sulfentrazone doses for each rain interval.

Table 2 - Plant density of Ipomoea quamoclit at 14 and 28 days after rain simulation (DARS) and shoot biomass at 28 DARS for different periods of rain simulation and sulfentrazone doses

\begin{tabular}{|c|c|c|c|c|c|c|c|c|c|}
\hline \multirow{4}{*}{$\begin{array}{l}\text { Rain simulation - } \\
\text { Days of herbicide } \\
\text { application }\end{array}$} & \multicolumn{9}{|c|}{ Sulfentrazone doses $\left(\mathrm{kg} \mathrm{ha}^{-1}\right)$} \\
\hline & 0 & 0.6 & 0.9 & 0 & 0.6 & 0.9 & 0 & 0.6 & 0.9 \\
\hline & \multicolumn{6}{|c|}{ Plant density (unit pot ${ }^{-1}$ ) } & \multicolumn{3}{|c|}{ Biomass $\left(\mathrm{g} \mathrm{pot}^{-1}\right)$} \\
\hline & \multicolumn{3}{|c|}{14 DARS } & \multicolumn{3}{|c|}{28 DARS } & \multicolumn{3}{|c|}{28 DARS } \\
\hline 0 & $12.75 \mathrm{~B}^{1 / /}$ & $0.88 \mathrm{~A}$ & $0.00 \mathrm{~A}$ & $21.25 \mathrm{~B}$ & $0.12 \mathrm{~A}$ & $0.00 \mathrm{~A}$ & $0.69 \mathrm{~B}$ & $0.05 \mathrm{~A}$ & $0.00 \mathrm{~A}$ \\
\hline 20 & $9.12 \mathrm{~B}$ & $0.25 \mathrm{~A}$ & $0.00 \mathrm{~A}$ & $15.88 \mathrm{~B}$ & $0.00 \mathrm{~A}$ & $0.00 \mathrm{~A}$ & $0.49 \mathrm{~B}$ & $0.00 \mathrm{~A}$ & $0.00 \mathrm{~A}$ \\
\hline 40 & $8.38 \mathrm{~B}$ & $1.62 \mathrm{~A}$ & $0.12 \mathrm{~A}$ & $22.50 \mathrm{~B}$ & $0.25 \mathrm{~A}$ & $0.00 \mathrm{~A}$ & $1.11 \mathrm{~B}$ & $0.00 \mathrm{~A}$ & $0.00 \mathrm{~A}$ \\
\hline 60 & $21.88 \mathrm{~B}$ & $0.38 \mathrm{~A}$ & $0.38 \mathrm{~A}$ & $30.38 \mathrm{~B}$ & $0.50 \mathrm{~A}$ & $0.25 \mathrm{~A}$ & $1.60 \mathrm{~B}$ & $0.01 \mathrm{~A}$ & $0.00 \mathrm{~A}$ \\
\hline 90 & $28.50 \mathrm{~B}$ & $1.00 \mathrm{~A}$ & $0.75 \mathrm{~A}$ & $34.88 \mathrm{~B}$ & $0.12 \mathrm{~A}$ & $0.00 \mathrm{~A}$ & $1.56 \mathrm{~B}$ & $0.00 \mathrm{~A}$ & $0.00 \mathrm{~A}$ \\
\hline LSD & \multicolumn{3}{|c|}{3.30} & \multicolumn{3}{|c|}{4.54} & \multicolumn{3}{|c|}{0.21} \\
\hline
\end{tabular}

1/ Based on Tukey's test at 5\% probability; averages are followed by capital letters, and different letters within each row (for the same DARS) indicate the differences among the three sulfentrazone doses for each rain interval.

I. quamoclit, whose data exhibited a linear trend, with a higher weight observed at the 90-day interval. The results obtained for this treatment at varying rain intervals could be the result of variations in environmental conditions, primarily temperature and photoperiod, along the time interval. The pots were maintained in a greenhouse in which certain environmental oscillations, such as temperature, photoperiod, and relative humidity, were not controlled.

Taken together, the data indicate that sulfentrazone application at $0.6 \mathrm{~kg} \mathrm{ha}^{-1}$ was sufficient for the adequate control of I. hederifolia and I. quamoclit in a dry environment, up to a period of 90 days without rain after herbicide application. Other studies have also assessed the efficacy of sulfentrazone in controlling Ipomoea species in sugarcane crop production (Viator et al. 2002; Jones and Griffin, 2008; Azania et al., 2009). The susceptibility of species in this genus to sulfentrazone has been attributed to a low metabolism rate of the herbicide by the plants along with inefficient antioxidant systems (Thomas et al., 2005). Because sulfentrazone promotes singlet oxygen production, antioxidant systems can reduce the damage caused to plants by the herbicide.

About the effect of the time interval between sulfentrazone application and the occurrence of first rain with straw, one study found that rain simulation 7 days after application did not affect the herbicide 
effectiveness on Cyperus rotundus (Simoni et al., 2006).

Data from the rain $\mathrm{x}$ straw interaction is presented in Tables 3 and 4. No differences were observed between straw treatments for both Ipomoea species at any of the herbicide doses used, except at $0.6 \mathrm{~kg} \mathrm{ha}^{-1}$ 14 DARS. In this situation, the treatment with straw was associated with a higher density of $I$. hederifolia. In addition, the 0.6 and $0.9 \mathrm{~kg} \mathrm{ha}^{-1}$ doses did not exhibit different effects under the two straw conditions and were both effective in controlling weeds.

The results indicate that $20 \mathrm{~mm}$ of rainfall after herbicide application was enough to leach sulfentrazone from the straw to the soil, as the biological effect on I. hederifolia and I. quamoclit remained unaffected. Simoni et al. (2006) also found that with the same rain quantity, sulfentrazone leached through $20 \mathrm{t} \mathrm{ha}^{-1}$ of sugarcane straw. However, the straw remaining on the soil hindered the

14 DAA

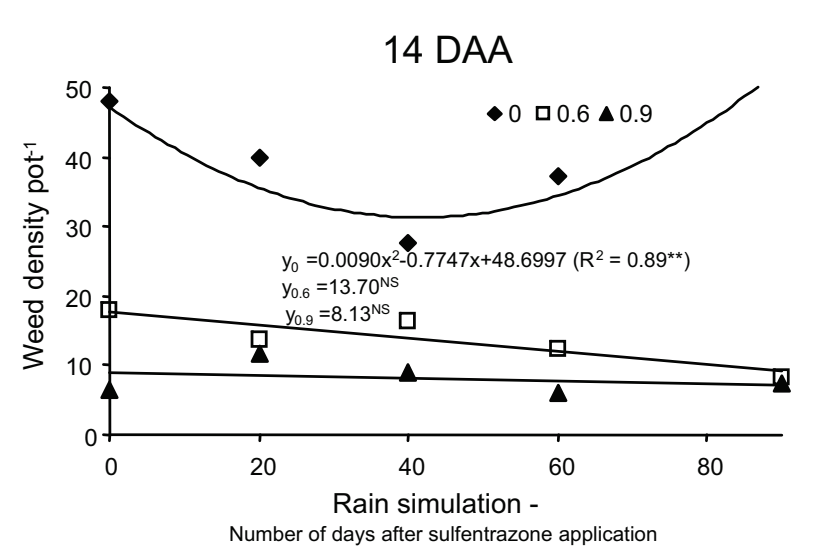

herbicidal control of $C$. rotundus. This effect may be related to the first method of herbicide dissipation in soil, microbial degradation (FMC Corp., 1995), which is directly or indirectly favored by increased straw on the soil. Alternatively, it could be due to photolysis or volatilization that the processes result in the leaching of the product from straw (Locke and Bryson, 1997) prior to the action of rainwater or irrigation.

In this study, the dissipative processes of the herbicide may have also occurred. However, sulfentrazone concentration in the soil solution was sufficient for the adequate control of the Ipomoea species. Even for species of the same genus, trials of this nature are very specific for the species studied, and the results obtained for one cannot be extrapolated to another because of the varying degree of susceptibility for each.

In the field experiment, the herbicide did not cause any visible damage to the sugarcane plants.
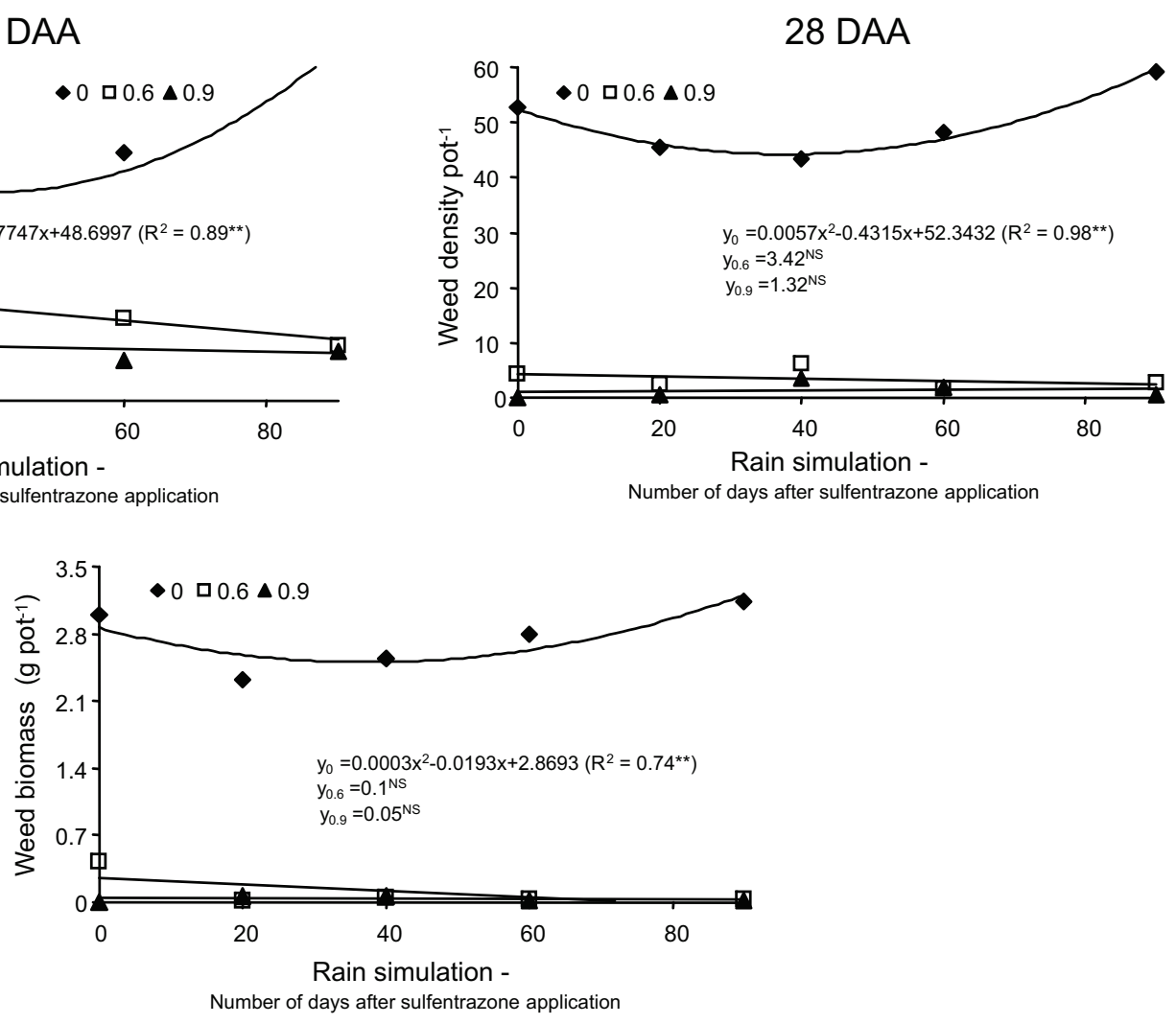

Figure 1 - Plant density of Ipomoea hederifolia at 14 and 28 days after rain simulation (DARS) and shoot biomass at 28 DARS, for different time intervals between sulfentrazone application and rain simulation and for different sulfentrazone doses. 
14 DAA

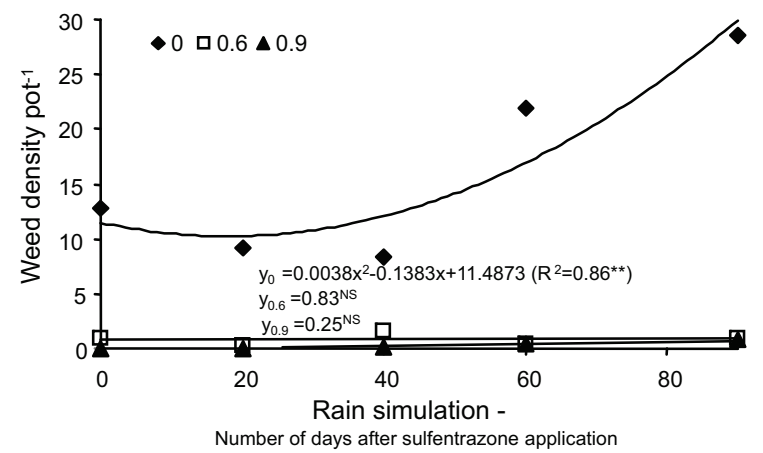

28 DAA

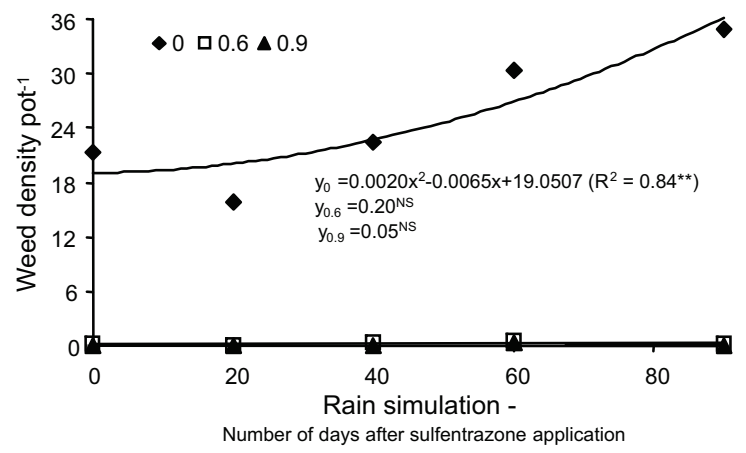

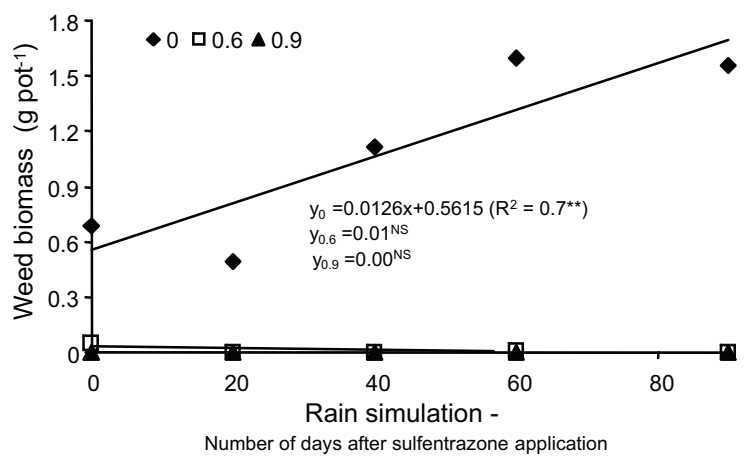

Figure 2 - Plant density of Ipomoea quamoclit at 14 and 28 days after rain simulation (DARS) and shoot biomass at 28 DARS, for different time intervals between sulfentrazone application and rain simulation and for different sulfentrazone doses.

In the assessments conducted 34 and 56 DAA, no emergence of weeds was observed at the experimental site, including the control without application. This was due to the extremely dry period (Figure 3), which prevented the germination and/or establishment by emerged seedlings.

When herbicide was sprayed on the straw, it was retained and leached into the soil only after the first rainfalls in September. Thus, unstable products susceptible to loss by volatilization and/or photodegradation certainly would not reach adequate concentrations in the presence of straw after a period of 60 days or more without rain, which occurred in this experiment. With approximately $140 \mathrm{~mm}$ of precipitation $92 \mathrm{DAA}$, on Oct 16, 2010, weed emergence occurred at the experimental site, specifically in the control without herbicide application, justifying the inclusion of the control assessment.

For treatments without straw, sulfentrazone was applied during a period of water scarcity, a condition that benefited its adsorption by soil colloids, discouraged microbial community development, and decreased the desorption of the herbicide by the colloids, making it unavailable for dissipation and leaching processes (Walker and Allen, 1984). Microbial degradation of sulfentrazone is higher at elevated temperatures (30 and $40{ }^{\circ} \mathrm{C}$ ) and in moist soil (30 to $70 \%$ of field capacity), where Nocardia brasiliensis and Penicillium sp. microorganisms have been identified as potential degraders of this herbicide (Martinez et al., 2010).

Each factor (herbicide and straw) and their interactions were significant for all the attributes assessed (Tables 5, 6, and 7).

For both Ipomoea species, the plant density was higher in the control without herbicide and without straw compared to the control without herbicide but with straw. However, the plants in the two control treatments grew and developed similarly and, in both cases, the plant density decreased over the course of 
Table 3 - Plant density of Ipomoea hederifolia at 14 and 28 days after rain simulation (DARS), and shoot biomass at 28 DARS, for different sulfentrazone doses and managed with or without sugarcane straw on the soil

\begin{tabular}{|c|c|c|c|c|c|c|}
\hline \multirow{4}{*}{$\begin{array}{c}\text { Sulfentrazone } \\
\text { doses } \\
\left(\mathrm{kg} \mathrm{ha}^{-1}\right)\end{array}$} & \multicolumn{6}{|c|}{ Straw $\left(\mathrm{t} \mathrm{ha}^{-1}\right)$} \\
\hline & 0 & 10 & 0 & 10 & 0 & 10 \\
\hline & \multicolumn{4}{|c|}{ Plant density (unit pot ${ }^{-1}$ ) } & \multicolumn{2}{|c|}{ Biomass $\left(\mathrm{g} \mathrm{pot}^{-1}\right)$} \\
\hline & \multicolumn{2}{|c|}{14 DARS } & \multicolumn{2}{|c|}{28 DARS } & \multicolumn{2}{|c|}{28 DARS } \\
\hline 0 & $36.50 \mathrm{~b} \mathrm{~A}^{1 /}$ & $45.15 \mathrm{c} \mathrm{B}$ & $48.40 \mathrm{~b} \mathrm{~A}$ & $51.25 \mathrm{~b} \mathrm{~A}$ & $2.33 \mathrm{~b} \mathrm{~A}$ & $3.18 \mathrm{~b} \mathrm{~B}$ \\
\hline 0.6 & $7.80 \mathrm{a} \mathrm{A}$ & $19.60 \mathrm{~b} \mathrm{~B}$ & $4.70 \mathrm{a} \mathrm{A}$ & $2.25 \mathrm{a} \mathrm{A}$ & $0.18 \mathrm{a} \mathrm{A}$ & $0.07 \mathrm{a} \mathrm{A}$ \\
\hline 0.9 & 6.60 a A & $9.65 \mathrm{a} \mathrm{A}$ & $2.60 \mathrm{a} \mathrm{A}$ & $0.05 \mathrm{a} \mathrm{A}$ & $0.03 \mathrm{a} \mathrm{A}$ & $0.00 \mathrm{aA}$ \\
\hline LSD (row) & \multicolumn{2}{|c|}{4.53} & \multicolumn{2}{|c|}{4.58} & \multicolumn{2}{|c|}{0.26} \\
\hline LSD (column) & \multicolumn{2}{|c|}{5.49} & \multicolumn{2}{|c|}{5.50} & \multicolumn{2}{|c|}{0.31} \\
\hline
\end{tabular}

$1 /$ Based on Tukey's test at 5\% probability; averages are followed by letters. Different lowercase letters within each column indicate differences among the sulfentrazone doses for each straw quantity. Different uppercase letters within each row (for the same DARS) indicate the differences between the two straw quantities for each sulfentrazone dose

Table 4 - Plant density of Ipomoea quamoclit at 14 and 28 days after rain simulation (DARS) and shoot biomass at 28 DARS, for different sulfentrazone doses and managed with or without sugarcane straw on the soil

\begin{tabular}{|c|c|c|c|c|c|c|}
\hline \multirow{4}{*}{$\begin{array}{c}\text { Sulfentrazone } \\
\text { doses } \\
\left(\mathrm{kg} \mathrm{ha}^{-1}\right)\end{array}$} & \multicolumn{6}{|c|}{ Straw $\left(\mathrm{t} \mathrm{ha}^{-1}\right)$} \\
\hline & 0 & 10 & 0 & 10 & 0 & 10 \\
\hline & \multicolumn{4}{|c|}{ Plant density (unit pot $^{-1}$ ) } & \multicolumn{2}{|c|}{ Biomass $\left(\right.$ g pot $\left.^{-1}\right)$} \\
\hline & \multicolumn{2}{|c|}{14 DARS } & \multicolumn{2}{|c|}{28 DARS } & \multicolumn{2}{|c|}{28 DARS } \\
\hline 0 & $11.60 \mathrm{~b} \mathrm{~A}^{\underline{1}}$ & 20.65 b B & $21.85 \mathrm{~b} \mathrm{~A}$ & $28.00 \mathrm{~b} \mathrm{~B}$ & $0.72 \mathrm{~b} \mathrm{~A}$ & $1.46 \mathrm{~b} \mathrm{~B}$ \\
\hline 0.6 & 0.45 a A & $1.20 \mathrm{a} \mathrm{A}$ & $0.25 \mathrm{a} \mathrm{A}$ & $0.10 \mathrm{a} A$ & $0.01 \mathrm{a} \mathrm{A}$ & $0.02 \mathrm{a} \mathrm{A}$ \\
\hline 0.9 & $0.30 \mathrm{a} \mathrm{A}$ & $0.20 \mathrm{a} \mathrm{A}$ & $0.15 \mathrm{a} \mathrm{A}$ & $0.00 \mathrm{a} \mathrm{A}$ & 0.00 a $\mathrm{A}$ & $0.00 \mathrm{a} A$ \\
\hline LSD (row) & \multicolumn{2}{|c|}{1.74} & \multicolumn{2}{|c|}{2.39} & \multicolumn{2}{|c|}{0.11} \\
\hline LSD (column) & \multicolumn{2}{|c|}{2.09} & \multicolumn{2}{|c|}{2.87} & \multicolumn{2}{|c|}{0.13} \\
\hline
\end{tabular}

1/ Based on Tukey's test at 5\% probability; averages are followed by letters. Different lowercase letters within each column indicate differences among the sulfentrazone doses for each straw quantity. Different uppercase letters within each row (for the same DARS) indicate the differences between the two straw quantities for each sulfentrazone dose.

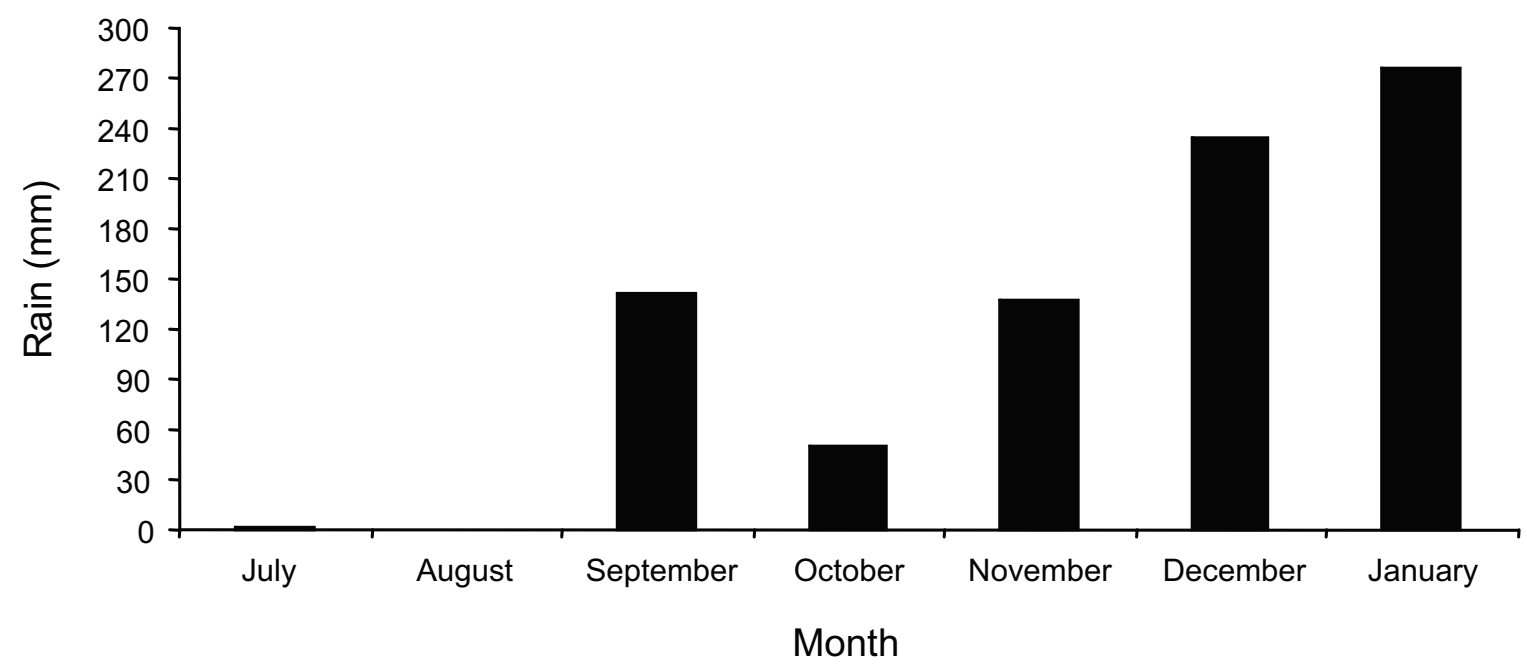

Figure 3 - Monthly rainfall recorded during the period between July 1, 2010 and January 31, 2011 using a rain gauge located $200 \mathrm{~m}$ away from the experimental site. 
Table 5 - Plant density (per $\mathrm{m}^{2}$ ) of Ipomoea hederifolia and Ipomoea quamoclit at 92 days after application (DAA) of herbicide, managed with or without sugarcane straw on the soil

\begin{tabular}{|c|c|c|c|c|c|}
\hline \multirow{3}{*}{$\begin{array}{l}\text { Herbicides/ } \\
\text { Control }\end{array}$} & \multirow{3}{*}{$\begin{array}{c}\text { Doses } \\
\left(\mathrm{kg} \mathrm{ha}^{-1}\right)\end{array}$} & \multicolumn{4}{|c|}{ Straw $\left(\mathrm{t} \mathrm{ha}^{-1}\right)$} \\
\hline & & 0 & 14 & 0 & 14 \\
\hline & & \multicolumn{2}{|c|}{ I. hederifolia } & \multicolumn{2}{|c|}{ I. quamoclit } \\
\hline Sulfentrazone & 0.600 & $0.03 \mathrm{a} \mathrm{A}^{1 / 1}$ & $0.00 \mathrm{a} \mathrm{A}$ & 0.00 a A & $0.00 \mathrm{a} \mathrm{A}$ \\
\hline Sulfentrazone & 0.900 & $0.10 \mathrm{a} \mathrm{A}$ & $0.00 \mathrm{a} \mathrm{A}$ & $0.00 \mathrm{a} \mathrm{A}$ & $0.33 \mathrm{a} \mathrm{A}$ \\
\hline $\begin{array}{l}\text { Sulfentrazone } \\
\text { Hexazinone }\end{array}$ & $\begin{array}{l}0.600 \\
0.250 \\
\end{array}$ & 0.00 a $\mathrm{A}$ & 0.00 a $\mathrm{A}$ & 0.00 a A & 0.00 a $\mathrm{A}$ \\
\hline Amicarbazone & 1.400 & $0.00 \mathrm{a} \mathrm{A}$ & $0.03 \mathrm{a} \mathrm{A}$ & $0.00 \mathrm{a} \mathrm{A}$ & $0.00 \mathrm{a} \mathrm{A}$ \\
\hline Imazapic & 0.147 & 0.80 a $\mathrm{A}$ & 0.03 a $\mathrm{A}$ & 0.07 a $\mathrm{A}$ & $0.00 \mathrm{a} \mathrm{A}$ \\
\hline Control & - & $18.25 \mathrm{~b} \mathrm{~B}$ & $13.00 \mathrm{~b} \mathrm{~A}$ & $10.00 \mathrm{~b} \mathrm{~B}$ & $7.75 \mathrm{~b} \mathrm{~A}$ \\
\hline \multicolumn{2}{|l|}{ LSD (row) } & \multicolumn{2}{|c|}{1.47} & \multicolumn{2}{|c|}{2.07} \\
\hline LSD (column) & & \multicolumn{2}{|c|}{2.62} & \multicolumn{2}{|c|}{2.50} \\
\hline
\end{tabular}

$1 /$ Based on Tukey's test at $5 \%$ probability; averages are followed by letters. Different lowercase letters within each column indicate differences among the herbicide/control treatments for each straw quantity. Different uppercase letters within each row (within the same species) indicate the differences between the two straw quantities for each herbicide/control treatment.

Table 6 - Percent control of Ipomoea hederifolia at 92 and 184 days after application (DAA) of herbicide, managed with or without sugarcane straw on the soil

\begin{tabular}{|c|c|c|c|c|c|}
\hline \multirow{3}{*}{$\begin{array}{c}\text { Herbicides/ } \\
\text { Control }\end{array}$} & \multirow{3}{*}{$\begin{array}{c}\text { Doses } \\
\left(\mathrm{kg} \mathrm{ha}^{-1}\right)\end{array}$} & \multicolumn{2}{|c|}{$92 \mathrm{DAA}$} & \multicolumn{2}{|c|}{184 DAA } \\
\hline & & \multicolumn{4}{|c|}{ Straw $\left(\mathrm{t} \mathrm{ha}^{-1}\right)$} \\
\hline & & 0 & 14 & 0 & 14 \\
\hline Sulfentrazone & 0.600 & $97.50 \mathrm{a} \mathrm{A}^{\frac{1 /}{1}}$ & 100.00 a $\mathrm{A}$ & $95.00 \mathrm{a} \mathrm{A}$ & $95.00 \mathrm{a} \mathrm{A}$ \\
\hline Sulfentrazone & 0.900 & $99.50 \mathrm{a} \mathrm{A}$ & 100.00 a A & $93.75 \mathrm{a} \mathrm{A}$ & $96.38 \mathrm{a} \mathrm{A}$ \\
\hline $\begin{array}{l}\text { Sulfentrazone } \\
\text { Hexazinone }\end{array}$ & $\begin{array}{l}0.600 \\
0.250\end{array}$ & 100.00 a A & 100.00 a A & 95.62 a A & 93.75 a A \\
\hline Amicarbazone & 1.400 & $100.00 \mathrm{a} \mathrm{A}$ & 99.50 a A & $96.12 \mathrm{a} \mathrm{A}$ & $95.62 \mathrm{a} \mathrm{A}$ \\
\hline Imazapic & 0.147 & $94.25 \mathrm{~b} \mathrm{~B}$ & $99.75 \mathrm{a} \mathrm{A}$ & 93.79 a A & $97.12 \mathrm{a} \mathrm{A}$ \\
\hline Control & - & $0.00 \mathrm{c} \mathrm{B}$ & $55.00 \mathrm{~b} \mathrm{~A}$ & $0.00 \mathrm{~b} \mathrm{~B}$ & $10.00 \mathrm{~b} \mathrm{~A}$ \\
\hline \multicolumn{2}{|l|}{ LSD (row) } & \multicolumn{2}{|c|}{2.79} & \multicolumn{2}{|c|}{5.95} \\
\hline \multicolumn{2}{|l|}{ LSD (column) } & \multicolumn{2}{|c|}{3.73} & \multicolumn{2}{|c|}{8.39} \\
\hline
\end{tabular}

1/ Based on Tukey's test at 5\% probability; averages are followed by letters. Different letters within each column indicate differences among the herbicide/control treatments for each straw quantity. Different uppercase letters within each row (for the same DAA) indicate the differences between the two straw quantities for each herbicide/control treatment.

Table 7 - Percent control of Ipomoea quamoclit at 92 and 184 days after application (DAA) of herbicide, managed with or without sugarcane straw on the soil

\begin{tabular}{|c|c|c|c|c|c|}
\hline \multirow{3}{*}{$\begin{array}{c}\text { Herbicides/ } \\
\text { Control }\end{array}$} & \multirow{3}{*}{$\begin{array}{c}\text { Doses } \\
\left(\mathrm{kg} \mathrm{ha}^{-1}\right)\end{array}$} & \multicolumn{2}{|c|}{$92 \mathrm{DAA}$} & \multicolumn{2}{|c|}{184 DAA } \\
\hline & & \multicolumn{4}{|c|}{ Straw $\left(\mathrm{t} \mathrm{ha}^{-1}\right)$} \\
\hline & & 0 & 14 & 0 & 14 \\
\hline Sulfentrazone & 0.600 & $100.00 \mathrm{a} \mathrm{A}^{1 /}$ & $100.00 \mathrm{a} \mathrm{A}$ & $98.25 \mathrm{a} \mathrm{A}$ & $95.62 \mathrm{a} \mathrm{A}$ \\
\hline Sulfentrazone & 0.900 & $100.00 \mathrm{a} \mathrm{A}$ & $100.00 \mathrm{a} \mathrm{A}$ & $99.50 \mathrm{a} \mathrm{A}$ & $96.50 \mathrm{a} \mathrm{A}$ \\
\hline $\begin{array}{l}\text { Sulfentrazone } \\
\text { Hexazinone }\end{array}$ & $\begin{array}{l}0.600 \\
0.250\end{array}$ & 100.00 a A & 100.00 a $\mathrm{A}$ & 97.50 a $\mathrm{A}$ & 95.75 a A \\
\hline Amicarbazone & 1.400 & 100.00 a A & $100.00 \mathrm{a} \mathrm{A}$ & $97.25 \mathrm{a} \mathrm{A}$ & $96.25 \mathrm{a} \mathrm{A}$ \\
\hline Imazapic & 0.147 & 99.50 a A & $100.00 \mathrm{a} \mathrm{A}$ & $90.00 \mathrm{~b} \mathrm{~B}$ & $95.00 \mathrm{a} \mathrm{A}$ \\
\hline Control & - & $0.00 \mathrm{~b} \mathrm{~B}$ & $60.00 \mathrm{~b} \mathrm{~B}$ & $0.00 \mathrm{c} \mathrm{B}$ & $15.00 \mathrm{~b} \mathrm{~A}$ \\
\hline \multicolumn{2}{|l|}{ LSD (row) } & \multicolumn{2}{|c|}{0.69} & \multicolumn{2}{|c|}{3.21} \\
\hline \multicolumn{2}{|l|}{ LSD (column) } & \multicolumn{2}{|c|}{1.00} & \multicolumn{2}{|c|}{4.77} \\
\hline
\end{tabular}

1/ Based on Tukeys test at 5\% probability; averages are followed by letters. Different letters within each column indicate differences among the herbicide/control treatments for each straw quantity. Different uppercase letters within each row (for the same DAA) indicate the differences between the two straw quantities for each herbicide/control treatment. 
the evaluation periods. This result could be explained by the adaptive capacity of weeds to grow and branch out by covering the soil under low density conditions, which si similar to or possibly exceeding their growth in environments with higher plant density. Therefore, intra-specific competition, between individuals of the same species, discourages the development of the population. In this regard, the different herbicide treatments produced different effects, regardless of the soil cover or the species assessed.

At 92 DAA, with straw on the soil at $14 \mathrm{t} \mathrm{ha}^{-1}$, no differences were observed among the different herbicides for the control of I. hederifolia. However, imazapic was less effective compared to the other treatments in the absence of straw. At 184 DAA, herbicide treatments did not differ under either straw condition.

For I. quamoclit, no differences were observed among the herbicide treatments when sugarcane straw remained on the soil, for both assessment periods. The same was true for conditions without straw 92 DAA. However, 184 DAA imazapic had the lowest herbicidal efficacy compared to the other treatments.

For all herbicide treatments, no differences were observed between the two straw conditions, except with imazapic, which exhibited better control of I. hederifolia (92 DAA) and I. quamoclit (184 DAA) with straw. For both straw conditions, the control of both species was superior to $90 \%$ 184 DAA.

With or without $14 \mathrm{t} \mathrm{ha}^{-1}$ of sugarcane straw on the soil, sulfentrazone alone $(0.6$ and $0.9 \mathrm{~kg} \mathrm{ha}^{-1}$ ) or in combination with hexazinone $\left(0.6+0.25 \mathrm{~kg} \mathrm{ha}^{-1}\right)$ was effective in the control of I. hederifolia and I. quamoclit and had herbicidal efficacy that was similar to or higher than amicarbazone $\left(1.4 \mathrm{~kg} \mathrm{ha}^{-1}\right)$ and imazapic $\left(0.147 \mathrm{~kg} \mathrm{ha}^{-1}\right)$.

\section{LITERATURE CITED}

AZANIA, C. A. M. et al. Manejo químico de Convolvulaceae e Euphorbiaceae em cana-de-açúcar em período de estiagem. Planta Daninha, v. 27, n. 4, p. 841-848, 2009.

CORREIA, N. M.; DURIGAN, J. C. Emergência de plantas daninhas em solo coberto com palha de cana-de-açúcar. Planta Daninha, v. 22, n. 1, p. 11-17, 2004.
CORREIA, N. M.; DURIGAN, J. C.; MELO, W. J. Envelhecimento de resíduos vegetais sobre o solo e os reflexos na eficácia de herbicidas aplicados em pré-emergência. Bragantia, v. 66, n. 1, p. 101-110, 2007.

FMC Corp. Technical bulletin of sulfentrazone Philadelphia: $1995.6 \mathrm{p}$

JONES, C. A.; GRIFFIN, J. L. Residual red morningglory (Ipomoea coccinea) control with foliar- and soil-applied herbicides. Weed Technol., v. 22, n.3, p. 402-407, 2008.

KISSMANN, K. G.; GROTH, D. Plantas infestantes e nocivas. 2.ed. São Paulo: BASF, 1999. 978 p. Tomo II.

LOCKE, M. A.; BRYSON, C. T. Herbicide-soil interaction in reduced tillage and plant residue management systems.

Weed Sci., v. 45, n.2, p. 307-320, 1997.

MARTINEZ, C. O. et al. Microbial degradation of sulfentrazone in a brazilian rhodic hapludox soil. Braz. J. Microbiol., v. 41, n.1, p. 209-217, 2010.

MERSIE, W. et al. Atrazine and metolachlor sorption to switchgrass residues. Comm. Soil Sci. Plant Anal., v. 37, n. 3-4, p. 465-472, 2006.

RODRIGUES, B. N. Influência da cobertura morta no comportamento dos herbicidas imazaquin e clomazone. Planta Daninha, v. 11, n. 1/2, p. 21-28, 1993.

RODRIGUES, B. N.; ALMEIDA, F. L. S. Guia de herbicidas. 6.ed. Londrina: Edição dos Autores, 2011. $697 \mathrm{p}$.

SENSEMAN, S. A. Herbicide handbook. 9.ed. Lawrence: Weed Science Society of America, 2007. 458 p.

SIMONI, F. et al. Eficácia de imazapic e sulfentrazone sobre Cyperus rotundus em diferentes condições de chuva e palha de cana-de-açúcar. Planta Daninha, v. 24, n. 4, p. 769-778, 2006.

THOMAS, W. E. et al. Uptake, translocation, and metabolism of sulfentrazone in peanut, prickly sida (Sida spinosa), and pitted morningglory (Ipomoea lacunosa).

Weed Sci., v. 53, n.4, p. 446-450, 2005.

VIATOR, B. J.; GRIFFIN, J. L.; ELLIS, J. M. Red morningglory (Ipomoea coccinea) control with sulfentrazone and azafeniden applied at layby in sugarcane (Saccharum spp.) Weed Technol., v. 16, n.1, p. 142-148, 2002.

WALKER, A.; ALLEN, J. G. Influence of soil and environmental factors on pesticide. Soil Crop Protec. Chem., v. 27, n. 1, p. 27-32, 1984. 